\title{
O INDIVÍDUO E O CIDADÃO NA HISTÓRIA DAS IDÉIAS (Com um ensaio sobre Maquiavel)
}

REGIS DE CASTRO ANDRADE

O termo "política", numa definição de máxima abrangência, designa a reflexão e uma ação de uma comunidade sobre si própria enquanto unidade in fieri, enquanto unidade sempre ameaçada e que deve ser permanentemente reposta. A compreensão prática ${ }^{1}$ da política nesses termos se nos apresenta como paradigma situado em um dos estratos mais antigos e profundos da cultura ocidental.

Toda ação política dá-se num campo de memórias, modos de pensar e sentir, e instituições - construções normativas da realidade próprias do universo vital - partilhados, que constituem a comunidade. A matéria da reflexão comunitária são a diversidade conflitiva de interesses, própria de todas as sociedades, o enfrentamento do esperado, implícito no tempo histórico e a preservação da anatomia face a poderes externos (divindades, tiranos, exércitos). Trata-se, sempre, de preservar, fortalecer ou mesmo recompor a unidade do grupo, base, desde logo, da identidade coletiva. Visto que permanentemente ameaçada, a vida livre e (relativamente ao menos) pacífica requer, a cada momento um esforço coletivo, marcado por contradições e de resultado incerto, de construção institucional ${ }^{2}$.

\footnotetext{
1 A expressão "compreensão prática" refere-se à natureza das proposições políticas. São elas proposições que: (a) contém a vontade de agir e não meramente de especular; (b) tem a pretensão de objetividade, i. e. , de validade para todos os seres racionais; (c) presumem, em (b), a possibilidade de uma concepção de "bom governo"; supõem, em conseqüência e necessariamente, em algum grau, a liberdade de escolha, sem a qual a normatividade moral e política seria impensável; (d) consistem em juízos nos quais se procura vincular a ação concreta, que contém sempre um elemento de contingência, a regras universais. Esse argumento foi bem desenvolvido por Kant na Crítica da Razão Prática. Poder-se-ia argüir que, diferentemente do que nos diz Kant, o contingente ou o empírico não é removível no plano teórico através de uma idéia reguladora, mas constituem a própria matéria da política.

2 As expressões "comunidade", "reflexão comunitária", "recomposição de unidade do grupo" e "identidade coletiva" referem-se todas a uma dimensão da política em que entidades coletivas ou a comunidade política têm precedência, na concepção dos fundamentos e finalidades da atividade política, sobre o cidadão individual. Tal como "comunidade", recebem vários nomes ao longo dos séculos: polis, república, civitas, nação, commonwealth, povo etc.
} 
Essa dimensão da política articula-se organicamente a uma outra: toda ação política implica escolha. A boa escolha diz respeito a fins bem escolhidos, e também a meios ou modos de agir regidos pela razão e pela prudência. Não se escolhe, senão excepcionalmente, em política, o que é necessário, mas o curso da ação que parece o mais razoável entre outros cursos possíveis. A política não é a realização de qualquer verdade meta-histórica ${ }^{3}$, mas a busca do bem público em situação. Sendo a interação social não virulenta (que supõe a liberdade, a igualdade, a justiça etc.) um valor universal, racionalmente aceitável, cabe aos sujeitos políticos realizá-lo nas circunstâncias dadas, adotando uma estratégia que lhes pareça a melhor, em termos de custos e benefícios (em sentido amplo, e não apenas econômico) em face de cursos de ação alternativos.

Filosofia e política reclamam-se mas não se confundem, entendendo-se que a primeira trata, em termos aristotélicos, das causas formal e final do viver em comunidade e a segunda, da matéria social à que se há de dar forma (à que se há de conferir ininteligibilidade moral). $\mathrm{O}$ argumento supõe a admissão de que a sociabilidade "natural", ou melhor, histórica, constitui-se de particularismos inelimináveis. Ao mesmo tempo, por nossa inserção numa arquitetura axiomaticamente (ou mesmo historicamente) racionalizável da existência social, somos atraídos, de modo irreversível, pela idéia de comunidade perfeita, invariável e eterna.

Como conciliar as duas dimensões da política nesse esquema de pensamento? Não é possível conciliá-los de todo, ainda que não sejam de todo contraditórias. Assim, temos de nos resignar à política como esfera da imperfeição - maior ou menor, não importa - ou recolher-nos à pura contemplação. Mas nos dois casos, condenamo-nos à insatisfação e à nostalgia (à condição humana?): à nostalgia, bem lá no fundo, do divino na política que se quer a um tempo leiga, não teocrática; à nostalgia do que deveria ter sido - aos fracassos da razão na história - e do que a política deverá ser, sem podê-lo. À história nos ligamos por laços de pertencimento e de estranhamento. No entanto, é no "baixo trato humano" de Camões que o universal, o sobre-humano pode manifestar-se; a razão não se exercita num mundo em que a revolução é impossível.

3 Ou seja não é a realização de verdades religiosas, metafísicas ou tal como concebidas numa filosofia de causalidade histórica. 


\section{A comunidade como referência central}

O tema da comunidade - o todo social, que não corresponde à soma de seus membros e que recebe várias denominações ao longo dos séculos - se entrelaça com o do cidadão desde o início da reflexão política no Ocidente. Mas a ênfase num ou noutro varia segundo épocas e autores. Grosso modo, o primeiro prevalece até o Renascimento; daí para a frente, o cidadão individual é o centro da atenção.

Senão por outra razão, seria útil dizer algo sobre o período prérenascentista para estabelecer um contraste com uma reflexão - por certo não descolada dos eventos históricos - que leva diretamente às concepções modernas da cidadania, questão central deste trabalho. Assim, as observações que seguem são indicativas e seletivas quanto aos autores.

É sabido que em Aristóteles toda associação humana, desde a família até a forma suprema de associação, se estabelece "segundo leis da natureza". O homem é um animal político. Segue-se que "a cidade ou estado tem prioridade sobre qualquer indivíduo entre nós. Pois o todo tem de ter prioridade sobre as partes. (...) o Estado é ao mesmo tempo natural e precede o indivíduo". Na polis, a propensão à associação se completa: alcança-se a auto suficiência. Se a família sustentava a vida, o Estado "está em posição de assegurar a boa vida" (Aristóteles,Política, I, 2)

A atividade política, no filósofo, tem uma decisiva dimensão moral, e envolve o estabelecimento de normas consensuais de conduta fixadas na politéia, termo usualmente traduzido para "constituição"4.

Importa observar que a "boa vida" corresponde ao pleno desenvolvimento de todas as faculdades ou potencialidades humanas - materiais, espirituais e afetivas - e que ela só se alcança no interior da polis. Fora da polis o homem se desumaniza, "enlouquecido pela guerra". O bem de cada um, portanto, requer a polis bem constituída: o consenso de todos sobre isso é possível porquanto natural, e ele é fundamento da idéia de bem comum como finalidade da política.

O aprendizado das leis que promovem o bem comum é, portanto, essencial; mas por aprendizado das leis não se deve entender educação legal, mas educação moral e social (Sinclair, [ed. Penguin] p. 22).

A Constituição, em Aristóteles, é feita pelos homens, mas homens agindo de acordo com sua natureza. De qualquer forma, a realização

\footnotetext{
${ }^{4}$ Sobre a necessidade de amplo consenso, ver Aristóteles, Política, IV, 12.
} 
do bem comum requer a participação de todos na elaboração das leis. Sem essa participação, as leis podem beneficiar a alguns e não a outros ${ }^{5}$. Daí a importância decisiva atribuída por ele ao exercício da cidadania. O cidadão aristotélico é um cidadão ativo, gozando da liberdade positiva de influir nas decisões que concernem a todos e na administração da justiça. O que caracteriza o cidadão é a titularidade de direitos políticos - o direito de participação ${ }^{6}$ (Mulgan [Aristotle's Political Theory,] 53-4).

$\mathrm{Na}$ concepção romana, tal como exposta por Cícero, o cidadão é um ser que, por sua natureza, é dotado de razão. A lei que constitui a comunidade política é expressão de entendimento racional, "de que nascemos para a justiça. A lei é uma força da natureza, a inteligência e a razão de um homem sábio, e o critério da justiça"(Cícero, Leis, I, 19). Em resumo, a estrutura básica do argumento ciceroniano seria este: a razão como função da natureza humana é capaz de produzir as leis que constituem a comunidade justa em que aspiramos viver.

Todas as virtudes, inclusive a política, são fins em si mesmas, isto é, não são jamais utilizadas para benefício próprio. A justiça como fundamento e finalidade da comunidade política, "não busca recompensa nem tem preço; é buscada por si mesma, e é a um tempo causa e o significado de todas as virtudes"(Cícero, Leis, I, 48) ${ }^{7}$. A associação política virtuosa por excelência é a República. “(...) a República é a propriedade do povo. Todavia o povo não é qualquer tipo de congregação humana, mas uma numerosa associação unida pelo consenso legal e pela comunidade de interesses" (Cícero, República, I, 39).

Não é difícil perceber afinidades entre Aristóteles e Cícero, sobretudo no plano das premissas da racionalidade e da sociabilidade naturais dos homens. Mas há entre os dois diferenças importantes.

Desponta em Cícero uma distinção entre direito do cidadão e direito do homem sábio. Aquele é garantido pela Lei Civil, este pela "lei

\footnotetext{
$5 \mathrm{O}$ regime oligárquico pode mais facilmente ser mais aceitável para os pobres, que são em maior número, do que a democracia. A primeira razão disso é que a oligarquia paga aos pobres que comparecem às Assembléias e tribunais de justiça e não multa os ricos que não comparecem; as democracias fazem o contrário. "É por isso que, se se deseja uma justa combinação de oligarquia e democracia, a coisa certa é convocar ambos os lados e estender a ambbos os pagamentos e multas"(Aristóteles, IV, 13). Mais adiante, Aristóteles argumenta que, qualquer que seja a sua forma, o bom governo deve proporcionar três coisas: (a) discussão e decisão sobre o que deve ser feito; (b) cargos executivos ocupados por cidadão das três classes (alta, média e baixa) e (c) um sistema judicial (Aristóteles, IV, 14).

6 Aristóteles III, 1-3. Ao definir a cidadania na Política Aristóteles começa por descartar alguns critérios errados: o de residência (pois que mulheres e escravos, residentes, não são cidadãos) e o de exercer o comércio, podendo o indivíduo processar e ser processado, pois isso pode derivar de tratados ou contratos comerciais.

7 "Salus populi suprema lex est".
} 
universal da natureza"(Cícero, República, I, 27). Essa distinção implica a remoção dos axiomas éticos da ordem jurídica ${ }^{8}$.

Em Cícero também se vislumbra uma distinção entre a esfera pública e a esfera privada. A República é uma finalidade em si. Em Aristóteles, a "boa vida" não se alcança senão pelo pertencimento a polis; o exercício da cidadania é conditio sine qua non e substância do bem viver.

A diferença realmente básica entre os dois autores reside em sua concepções de cidadania. Cícero inova nesse ponto. Em Aristóteles, requer-se a igualdade entre os cidadãos. Mas como os homens não são iguais (os homens são superiores às mulheres, os homens livres aos escravos, os proprietários aos indigentes) a cidadania é o atributo de um pequeno número, um seleto grupo de pessoas. Cícero, pelo contrário, afirma a igualdade entre todos os seres humanos: "não há nada que se pareça mais com outra coisa do que todos nós uns com os outros" (Cícero, Leis, I, 29). Essa igualdade cidadã se fundamenta como segue: "Todos os que foram dotados pela natureza com a razão também foram dotados com a correta razão, e portanto, com a lei, que é a aplicação da correta razão em comandos e proibições. Segue-se que os que [são dotados pela natureza] com a lei [a aplicação política da razão correta] são também dotados com a justiça. Mas a razão foi atribuída [pela natureza] a todos; portanto, o mesmo se aplica à justiça" (Cícero, Leis, I, 33) ${ }^{9}$. Isso significa que deve-se reconhecer em todos sua dignidade humana. Os escravos não são, como em Aristóteles, "ferramentas vivas", mas algo como trabalhadores vitalícios a serviço de um senhor. Nas palavras de Sabine, "como disse Kant, dando forma, dezoito séculos depois, ao antigo ideal, é preciso tratar o homem como fim e não como meio. O assombroso é que Cícero (...) aproxime-se mais de Kant que de Aristóteles" (Sabine, 130).

Pois que tudo, inclusive os homens, tem um princípio divino, não podemos restringir a cidadania a um local, aos muros de uma CidadeEstado: reconhecemo-nos como "cidadãos de todo o mundo" (Cícero, I, 61). A cidadania é um atributo de toda a humanidade.

Tal ampliação conceitual relaciona-se com a expansão histórica da Roma republicana e justifica o fortalecimento política da sua cidadania: a República, a partir do contato entre patrícios e plebeus, admite o casamento entre pessoas das duas classes, permite o acesso de pessoas da plebe ao con-

\footnotetext{
8 A distinção apenas desponta em Cícero, que não faz uma distinção clara entre ius civile, por um lado, e ius gentium e ins naturale, por outro.

9 Minha tradução da edição inglesa. As interpolações entre colchetes também são minhas. Preferi traduzir "right reason" por "correta razão" ao invés de "justa razão".
} 
sulado, institucionaliza assembléias exclusivamente populares, os tribunos do povo, etc. No estágio final desse processo, no decorrer do século IV A.C., já se pode falar de um ordenamento patrício-plebeu (Mateucci, 1111).

Aristóteles distinguia entre três formas de constituição segundo o número dos detentores do poder (um só, poucos e muitos). Cada uma delas poderia ser boa - no caso de governo orientado pelo bem comum ou má, ou degenerada, caso o governo favoreça interesses particulares. Cícero admite a classificação segundo o número dos que exercem o governo. Mas as formas degeneradas de Aristóteles para ele deixam de ser estados: são agrupamentos sem fundamento na justiça, que mais tarde Agostinho denominará magna latrocínia.

$\mathrm{Na}$ Idade Média, a idéia de cidadania desaparece na medida em que a polis e a República como comunidades políticas são substituídas pela concepção da coletividade organizada como república christiana, que associa a ordem e a unidade da sociedade cristã à coordenação da Igreja e dos poderes temporais, "ambos instituídos por Deus para manter, sobre a terra, a paz e a justiça". Foi esse o princípio basilar da "grande síntese política da Idade Média" (Mateucci, [verbete "República"]1108).

O pensamento patrístico abandona a tradição do Velho Testamento, em que se contempla uma sociedade verdadeiramente universal - a dos adoradores do Deus de Israel - e em que, contraditoriamente, se atribui essa universalidade apenas ao povo judeu. $\mathrm{O}$ apóstolo Paulo desfaz essa contradição: "não há distinção entre judeu e grego, uma vez que o mesmo Cristo é o Senhor de todos, rico para com todos os que invocam" (Romanos, 10, 12). "Fazendo de todos os fiéis - e a lei é oferecida a todos - membros de um mesmo corpo místico, essa doutrina fixava, de uma vez por todas, a natureza da nova sociedade" (Gilson, 193).

De início, essa nova sociedade opunha-se ao poder temporal: no Apocalipse, a grande Babilônia sustentada pela Besta de sete cabeças refere-se a Roma.

Após a adoção do cristianismo por Constantino no século III, a Igreja, antes oposta ao poder imperial, passa a interagir com ele. Cresceu a influência da hierarquia eclesiástica; como cristãos, os próprios imperadores deveriam submeter-se a ela. É nesse contexto que escreve Agostinho, no século IV, A Cidade de Deus, "obra de imenso alcance por sua influência sobre o pensamento cristão, visto que todo pensamento político da Idade Média se inspirava nela" (Gilson, 196).

$\mathrm{Na}$ doutrina agostiana, os homens pertencem simultaneamente a duas. Cidades - a de Deus e a terrena. Naquela, perfeitamente ordenada, 
reina "harmonioso companheirismo em deus; a paz de todo universo é tranquilidade da ordem - e a ordem é uma disposição de coisas iguais e desiguais num padrão em que cada coisa ocupa sua posição apropriada (Agostinho, XIX, 13) ${ }^{10}$. A ordem temporal foi criada por Deus e ordenada segundo a perfeita justiça; a liberdade natural, no entanto, é perdida quando os homens, cedendo às tentações do demônio, pecam. Para que a Cidade Humana não se desagregue em violência interna e externa - e Agostinho tem o destino de Roma sob os olhos - ela requer "a direção divina". Sob essa direção, os homens saberão manter a paz em uma Cidade obedecendo a "duas regras: primeira, não causar dano a ninguém; segunda, ajudar aos outros sempre que possível" (Agostinho, XIX. 14-15).

A paz na Cidade celestial é eterna; na dos homens, é precaríssima (tal como observava, aliás, nos séculos da decadência do Império). O rompimento da paz eqüivale, em Agostinho, à perda da liberdade natural "dos que, destinados à liberdade perfeita no céu peregrinam na terra", onde não encontram a felicidade a que aspiram.

Esse poderoso argumento, finamente apresentado, é prenhe de conseqüências políticas. Pode-se destacar duas como as mais importantes.

A Civitas Dei, concebida por Agostinho como uma Cidade mística e atemporal, apresentava-se, na origem temporal, sob a forma da Igreja, como organização não apenas religiosa mas também política: omnium enim Christianorum una respublica est (Agostinho, De opere monachorum, in Gilson, 307). A Igreja de Roma "tem autoridade sobre todos os povos e sob ela, como mãe única e única cabeça, as nações do mundo inteiro estão reunidas" (cit. por Gilson, 307).

O populus romano é substituído pelo populus christianus, e a Respublica pela respublica christianorum. A ordem espiritual reina sobre a ordem política temporal, pois que só ela é capaz de vivificar e pacificar a sociedade humana para sempre ameaçada de destruição, desordem e violência.

A posição de Agostinho sobre Cícero ilustra bem essa visão de mundo. Cícero deplora a deterioração moral de Roma em seu tempo; o império já não era uma república. A causa disso era "a falta de homens notáveis". Ao mesmo tempo, Cícero é nostálgico da "antiga moralidade dos governantes de antanho", sob cuja direção imperava a moralidade pública e a sociedade se organizava segundo o princípio da justiça. Pergunta Agostinho: não seria a visão ciceroniana da antiga Roma apenas

10 Agostinho desenvolve o contraste entre duas cidades em XVI. 28 e em XV, passim 
uma "visão fantasiosa”? E continua: “(Roma) é certamente uma república até certo ponto, (...) e foi a melhor governada pelos antigos romanos. Mas a verdadeira justiça só existe naquela república cujo fundador e governante é Cristo"(Agostinho, II. 21)

As virtudes cívicas do pensamento político romano são substituídas pelo acatamento da autoridade da Igreja. A salus populi como supremo bem é substituída pela salvação da alma, através da expansão na terra da comunitas christiana. Gilson vê na cristianização do império um "desenvolvimento radicalmente novo" no pensamento político ocidental.

(b) A segunda consequiência política do agostinismo está diretamente relacionada com o tema central deste trabalho, que é a história da cidadania.

Agostinho reconhece a existência, no homem, de uma "alma racional" que possibilita "o pensamento deliberado" e a "ordenação de sua vida e de seus padrões morais de acordo com os conhecimentos adquiridos". Mas "a mente humana é fraca", sempre perturbada, ademais, pelos desejos. Por isso, ele "necessita da direção divina, que ele pode obedecer resolutamente, e da assistência divina, que ele pode obedecer livremente". E "enquanto possui um corpo mortal, ele é um peregrino numa terra estrangeira, apartado de Deus; portanto em sua marcha ele se orienta pela fé, e não pela visão" (Agostinho, XIX, 14).

Perde-se, aqui, a confiança greco-romana nas faculdades da razão, inclusive na possibilidade de ordenação da sociedade segundo os princípios racionais da justiça.

A admissão da "alma racional" implica reconhecimento da capacidade de escolha entre o bem e o mal ou do livre arbítrio. Sabe-se das infindáveis discussões teológicas sobre a questão. O que importa aqui é, sem assistência divina, os homens podem (embora não o façam necessariamente) sucumbir ao erro e às tentações do diabo.

Essa doutrina está na base da transformação, por Agostinho, do cidadão ciceroniano, que é livre na medida em que participa, pelo uso da razão, da vida política da República e da administração da justiça, em cristãos obedientes. Os dois modos de inserção dos indivíduos na sociedade não são incompatíveis; mas as virtudes cristãs não mais são exigíveis e justificáveis porque a autoridade do governo deriva do povo, mas porque é um dever imposto por Deus. $\mathrm{O}$ cristão está portanto inserido em duas ordens de lealdades: a do Estado e a de Deus. No caso de exigências conflituosas entre as duas, não há dúvida sobre a precedência da obediência aos mandamentos divinos (Sabine, 142). 
Deus criou o homem em liberdade, que pode-se perder pelo pecado. Assim se justifica a escravidão em Agostinho (e não pelas leis da guerra, como no mundo greco-romano). Mais uma vez, estamos diante de um turning point decisivo no campo das idéias políticas (embora Agostinho vá buscar na Bíblia a justificação do seu argumento). Assim, a servidão humana em Agostinho tem duas dimensões: os servi são escravos dos seus pecados e de outros homens. Pelo pecado, ele infringe a ordem natural do mundo criado por Deus; a "disciplina da escravidão" é a punição por aquela infração. Como libertar-se? "Se (os escravos) não podem ser libertos por seus senhores, eles podem, num certo sentido, libertar-se a si mesmos, servindo não com ardis decorrentes do medo, mas com a fidelidade da afeição, até que toda injustiça desapareça e todo poder do senhor se desfaça, e Deus seja tudo em todos" (Agostinho, XIX. 16). Também é verdade que "a servidão é benéfica para alguns [os pecadores] e essa servidão é, para Deus, ao menos, benéfica para todos" (Agostinho, XIX, 21).

O cristão deve obedecer antes de mais nada a Deus, não aos homens. As observações de Agostinho sobre a escravidão são extensíveis à esfera das relações familiares e políticas. Está claramente implícita em Agostinho a idéia de que os cristãos devem obedecer mesmo aos maus governantes: se eles se submetem a um tirano, isso decorre da impiedade dos súditos.

Escrevendo no século XIII, Tomás de Aquino está imerso na tradição medieval do pensamento político; mas ele formula de modo original velhas doutrinas e desfaz-se delas em alguns pontos, prenunciando, de alguma forma, novos modos de pensar.

Aquino acolhe a distinção entre vida espiritual e vida terrena, entre teologia e filosofia, mas no volume 28 da Summa Theologiae (Law and Political Theory), a lei humana, (que se baseia na lei natural e vincula-se, por essa via, à lei eterna) recebe um tratamento específico. À diferença de Agostinho, e sob influência de Aristóteles, a lei dos homens visa o bem comum, por certo, mas (a) o bem estar do povo é possível na terra; "a lei ocupa-se sobretudo com a ordenação das coisas para a felicidade humana" (Summa, Q 90, 2); (b) como "princípio de direção e medida", a lei é produto da razão, que tem acesso à lei natural, manifesta na harmonia do universo (Summa, Q1, 1); (c) quanto à origem, a lei provém "do povo em seu todo" ou "da autoridade pública que dele cuida" (Summa, Q9, 3).

A ampliação da grande autonomia da esfera civil é registrada no Apêndice 6 da edição autorizada da Summa, onde se lê: "São Tomás parece ter sido o primeiro a ter idéia da responsabilidade e independência que 
advogados e homens de Estado devem ter nos seus respectivos campos de atuação" (Summa, Apêndice 6, p. 177).

Ainda na linha de uma reflexão que se antepõe a Agostinho, Aquino herdou o ideal helênico da natureza política do homem. "Nós realmente pertencemos à cidade terrena, que não é apenas um estágio na peregrinação ou um meio de uma santificação que se encontra em outro lugar, mas um valor verdadeiro em si mesma, e um objetivo da ação virtuosa" (Summa, Apêndice 8, p. 184).

A communitas ou o populus aquiniana é parte da ordem universal criada por Deus, mas já não é o populus christianum da tradição agostiniana. Aquino não dá muita atenção à complicada relação entre sacerdotium e imperium. A completa separação entre as duas ordens será teorizada por Marsílio de Padua no século XIV na esteira de Aristóteles e, indiretamente, de Aquino.

O livro de Marsílio de Padua Defensor Pacis é geralmente considerado uma das mais notáveis criações do pensamento político medieval. A principal referência filosófica de Marsílio é Aristóteles. No quadro dos conflitos políticos generalizados entre as cidades- estado italianas no século XIV, ele estuda as causas da discórdia e das revoluções tais como discutidas no Livro V da Política, e observa que entre elas não está, como não poderia estar, a causa principal da desordem na Itália: as pretensões papais de exercer um poder supremo sobre os governantes.

Dando por assente a visão aristotélica da comunidade autárquica, capaz de prover as necessidades físicas e espirituais dos cidadãos - o que não colidia com o aristotélismo medieval - Marsílio dela tira conclusões radicalmente novas. As sociedades humanas são autarquias no sentido pleno da palavra e, visto que a religião tem conseqüências sociais, deve ser objeto de regulação pela autoridade temporal. Invertem-se aqui os termos em que se concebia a relação entre as duas ordens: o poder espiritual não tem primazia sobre o humano. Essa inversão requer a nítida separação entre razão e revelação. Os preceitos religiosos são aceitos exclusivamente pela fé; as questões terrenas devem ser submetidas ao crivo da razão. Em sua taxonomia das leis, Marsílio rompe com Tomás. A lei humana não se vincula à lei eterna por mediação da lei natural; em Marsílio "a lei divina é um mandamento direto de Deus, sem deliberação humana; (...) a lei humana é um mandamento de todo o corpo de cidadãos, ou de sua parte de mais valor (valentiorem partem), que surge diretamente da deliberação dos que estão autorizados para elabora-la". A distinção é levada às últimas consequiências. A norma que implica penalidade terrena no caso de 
transgressão é uma lei civil. Como o poder espiritual não dispõe de força coativa, ele não tem autoridade no mundo leigo. Assim, Marsílio descarta de modo absoluto o direito canônico como jurisdição distinta: suas normas dizem respeito a valores espirituais, não aos negócios humanos.

Wolin credita a Aquino a revalorização da política após o eclipse medieval, "preparando o caminho para Maquiavel" (Wolin, 152). Uma interpretação alternativa atribuiria a Aquino o papel de sociedade politicamente autônoma; o autor que levou esse processo à sua culminação (à ruptura) foi Marsílio de Pádua, que, retomando a tradição clássica republicana, contrapõe-se porem à injustiça com valores espirituais - no caso, os da comunidade cristã - para sempre presentes na vida social. Restaria contrapor a república à ordem natural, o contingente e perecível ao permanente, a decisão individual de risco às arquiteturas da razão, o poder político à ética. Isso será obra do Renascimento, período em que nascem os conceitos modernos de política e de cidadania.

\section{$O$ cidadão renascentista}

Pocock, em seu The Machiavellian Moment, abre o capítulo III (sobre a vita activa e o vivere civile) com as seguintes observações:

"Pode-se argüir que o ideal do cidadão implicava uma conceituação totalmente diferente dos demais modos de conhecimento político e ação relativamente à conceituação implícita na moldura escolástica costumeira (...). Nos limites dessa moldura, o indivíduo empregava a razão, que lhe descortinava as externas hierarquias de natureza imutável e que o chamava a manter a ordem cósmica ocupando o seu lugar na categoria social e espiritual à qual era destinado por sua natureza individual; ele empregava a experiência que revelava continuidades imemoriais de comportamento tradicional e que só poderia aconselha-lo a mante-las; e ele empregava um misto de prudência e fé nas ocasiões em que o fluxo de eventos contingentes e particulares confrontava-o a um problema tão individual que nem a razão, nem o silogismo, nem a experiência, nem a tradição poderiam ajuda-lo a resolver. Somente nessas ocasiões, pode-se argumentar, ele se comportou como um animal decisor (decisiou-making) (...); quanto ao mais, seu comportamento era o de um habitante de (...) uma sociedade tradicional (...)".

A tal indivíduo se oporia um outro, constantemente envolvido, com seus parceiros, na tomada de decisões coletivas, e que "dispõe de um equipamento intelectual que o leva para além da percepção da hierarquia e 
da tradição". Esse indivíduo reconheceria em si próprio e no parceiros o poder de entender e confrontar os eventos que lhe dizem respeito. "Uma comunidade costumeira num canto da ordem eterna não é uma república de cidadãos". Se os indivíduos acreditam na tradição, não usarão seu poder para enfrentar eventos contingentes; se confiam na prudência de uns poucos, aceitarão qubernaculum monárquico; e se eles vêem na hierarquia universal a matriz de todos os valores, não se unirão como corpo soberano decisores.

"O cidadão tem de ter uma teoria do conhecimento que permita uma grande latitude nas decisões públicas. Tentar a construção de um modo civil de vida sobre questões epistemológicas que permitam apenas o reconhecimento da ordem universal e das tradições particulares significa sujeitar-se a certas limitações. Pode-se argumentar que a história do pensamento político florentino é a história de uma notável, embora parcial, emancipação dessas limitações" (Pocok, pp.49-50).

Na nova concepção política florentina a partir do século XV:

- a república não é eterna, pois não pertence à ordem da natureza. Uma concepção que vê a república e a cidadania como realidades primeiras (e não reflexas) teria necessariamente de separar a política da ordem natural, e teria de se organizar para afirmar sua soberania e autonomia, e portanto sua individualidade e particularidade (Pocock, p.53);

- a vita activa prima sobre a vita contemplativa, entendendo-se pela primeira expressão uma vida dedicada às questões cívicas e o exercício político da cidadania, e pela segunda uma vida dedicada à busca filosófica do puro conhecimento. $\mathrm{O}$ vivere civile, conseqüência da vita activa, envolve a participação e a ação no âmbito de uma estrutura social que torna possível tal modo de viver individual - ou seja, numa configuração constitucional que permita o exercício da cidadania (Pocock, p.56).

Desenvolve-se uma visão do mando que os estudiosos caracterizam como "humanismo cívico": os homens, com suas idéias, valores, ações e estilos, bem como as relações entre homem particulares passam a ocupar lugar central na constituição, destino e morte das repúblicas, dali removendo a "comunidade" natural e eterna como foco da reflexão política. Essa nova postura envolve uma renovada idéia de consciência republicana, a valorização da vida ativa e da retórica como modo de expressão adequado ao vivere civile, (por oposição à filosofia, adequada à vita contemplativa); 


\section{AÇÃO POLÍTICA E VALORES EM MAQUIAVEL}

\section{O Príncipe: homem de ação}

A política dos príncipes italianos descreve-se, num primeiro momento, como um fazer permanente; o seu tempo é, antes de mais nada, o dia a dia. Ele inventa, constantemente "novos estratagemas" adequados às novas situações que se sucedem, decide "no curso dos acontecimentos". O Príncipe é sobretudo um homem de ação ${ }^{11}$, devotado à consecução dos objetivos pragmáticos do seu métier ${ }^{12}$. A Vita de Costruccio Castracani é uma biografia paradigmática desse tipo de personagem ${ }^{13}$. No capítulo XX de $O$ Príncipe, Maquiavel pergunta-se se "as fortalezas e muitas outras coisas que a cada dia são feitas pelos príncipes são úteis ou não"; não se pergunta se são boas ou más.

Mas em que sentido deve-se entender a ação maquiaveliana? Duas leituras são possíveis. Ou bem entendemo-la como ação estratégica individual, orientada pela racionalidade instrumental, ou bem se a interpreta à maneira de Aristóteles: a ação tem em vista, sim, o contingente e o particular, mas o particular atualiza valores e razões universais. Essa questão será retomada mais adiante. Por ora, convém dizer algo sobre as circunstâncias históricas e culturais em que surge e atua o Príncipe.

\section{A emergência do Príncipe no Renascimento italiano}

Nosso personagem surge e opera numa formação políticohistórica e cultural singular. Seu advento vincula-se a pelo menos cinco características dessa formação no século $\mathrm{XV}$ até a primeira metade do século XVI.

A primeira é a fragmentação política da Itália, por sua vez associada, pós Maquiavel, à política da Santa Sé (preocupada em evitar o surgimento de poderes temporais nacionalmente hegemônicos) ${ }^{14}$. Esse "mosaico de Estados de dimensões territoriais, regimes políticos, estraté-

${ }^{11}$ Larivaille, Paul. A Itália no Tempo de Maquiavel. São Paulo. Companhia das Letras, 1988, pp. 22,23 e 111.

12 Sobretudo os "novos príncipes"; mas os príncipes hereditários tampouco podem ignorar as exigências do seu dia a dia.

13 Machiavelli. The Life of Castruccio Castracani, in The Prince, Wordsworth, U.K. No texto como Vita.

14 Machiavelli. The Discourses or The First Decade of Titus Livius. Penguin Books, 1970, cap. XX. 
gias de desenvolvimento econômico e até culturas muito variáveis (...) favorece os particularismos e ao mesmo tempo as rivalidades intermináveis"15.

A segunda é o desenvolvimento, nos dois séculos anteriores, de fortunas comerciais que constituíram as "grandes famílias", cuja influência no negócios públicos se consolidou ao longo do tempo e que travariam entre si uma luta interminável e selvagem pelo poder ${ }^{16}$. São personagens centrais na cena maquiaveliana os Medici em Florença, os D'Este em Ferrara, os Colonna e os Orsini nos Estados Pontifícios, os Sforza em Milão, os Borgia em várias cidades da Itália central, etc. O confronto entre eles tornava a forma de uma luta de facções que envolvia inevitavelmente alianças com os príncipes e conspirações entre eles, num caleidoscópio de lealdade precárias e inimizades.

A terceira é o estado de insegurança permanente em que viviam os príncipes. A demarcação entre repúblicas e principados é incerta, e não serviria como critério para avaliar o grau de segurança alcançado aqui ou ali. Maquiavel subestima, talvez, no plano local, o que ele contrapõe no plano geral: à insegurança geral ele contrapõe a menor dificuldade de conservar os Estados hereditários se comparados aos Estados novos. Naqueles, "bastaria não violar os costumes ancestrais e usar prudência ao lidar com as circunstâncias à medida em que elas mudam para que o príncipe se mantenha"17. Na sua apreciação do caso de Ferrara, por exemplo, ele "não dá atenção às múltiplas intrigas e aos esforços incessantes que o poder ducal fez para assegurar a sua tranqüilidade face aos muitos perigos que o ameaçam, tanto internos quanto externos" 18 .

A quarta característica é a sucessão de intervenções e ocupações armadas na Itália por parte dos potências unificadas da Europa. Estimuladas pela divisão e consequentemente debilidade interna da Itália, França, Espanha, Áustria e Alemanha buscavam ali fortalecer suas posições imperiais, apoderar-se de suas riquezas materiais do país e influir na política do Vaticano. A relação entre essas potências e os "grandes" locais, príncipes, facções, cardeais, papas e condottieri se descrevem como um intrincado fluir de alianças e de hostilidades determinadas pelas conveniências das lutas internas. A ameaça externa não despertou, na Itália,

15 Larivaille, P. op. cit. p.9.

16 Procacci, G. History of the Italian People. Penguin Books, 1991, passim.

17 Machiavelli. The Prince, Wordsworth, 1993, cap. II, p. 11.

18 Larivaille, P. op. cit. p. 37. 
tendências para a unificação; quando menos, tornou mais amargos os conflitos locais.

Extremamente importantes, enfim, são as mudanças culturais na Renascença italiana com respeito ao mundo medieval.

No plano metodológico, a ofensiva crítica dirigiu-se contra a utilização conservadora de Justiniano pelos seus glosadores ${ }^{19}$. Os humanistas contrapunham-se à tese escolástica, deliberadamente a-histórica, segundo a qual o principal objetivo dos juristas seria o de adaptar a letra da lei às circunstâncias vigentes; uma correta apreciação do Código, diriam os críticos, exigia uma reinterpretação inteiramente nova à luz das novas técnicas históricas e filológicas. O direito romano, afirmou-se, é produto de uma cultura distinta. Abriu-se assim o caminho para o estudo comparado dos diversos sistemas legais, de forte impacto no pensamento político do quattrocento ${ }^{20}$.

No plano da filosofia, a crítica humanista volta-se contra a valorização escolástica da contemplação como norma suprema do bem viver cristão enquanto pensante. À vita contemplativa substitui-se a vita activa: a participação refletida dos cidadãos nas deliberações sobre questões de interesse público. A filosofia se reorienta para o enfrentamento de questões práticas da vida social, e para o exame "da natureza humana, os propósitos para os quais nascemos e rumo aos quais nos dirigimos". Os escolásticos, queixa-se Petrarca, dizem muitas coisas que, "mesmo que verdadeiras, em nada contribuirão" para enriquecer nossas vidas ${ }^{21}$.

A revolução intelectual do humanismo renascentista introduz também uma nova concepção do tempo. A eternidade, o sempiternum hodie da ordem divina desvincula a duração do movimento; o tempo histórico não é relevante, ou mesmo sequer pensável22. Do "estar sempre presente" (nunc stans) como uniformização da diversidade histórica na comunidade eterna da Civitas Dei, o humanismo passou à temporalidade secular e histórica da Civitas Terrena. A salvação - como quer que se

19 o Codex Justinianum, de 529, o Digesta, de 530, contem respectivamente um novo Código de ordenamentos imperiais e uma codificação dos juristas romanos. Ambos foram referências obrigatórias para os estudos legais durante os séculos subsequentes.

20 Skinner, Quentin. As fundações do pensamento político moderno. São Paulo. Companhia das Letras, 1996, pp. 220-227.

21 Petrarca, citado por Skinner, p. 127.

22 Interrogando-se sobre essa questão, Agostinho escreveu: como podem "o passado e o futuro $s e r$, posto que o passado já não é e o futuro não chegou a ser?" E ainda: "como podemos dizer que mesmo o presente $\grave{E}$ visto que a razão pela qual $E$ é a de $n a \tilde{o}$ ser", ou seja, a de transformarse em passado? Saint Augustine, Confessions, Penguin, 1977, XI, 14, pp. 263-4. O único tempo concebível, nesse argumento, é o "interminável presente", a ordem eterna. 
entenda o termo - estaria agora na história e na sociedade, no enfrentamento da contingência e do conflito e não mais na realização de valores revelados ou na legislação derivada da Lei Divina, como em Aquino ${ }^{23}$.

\section{A metáfora homérica}

Do ponto de vista dos que trataram da política na Itália do Renascimento tardio - na época de Maquiavel - privilegiava-se a narrati$v a$ com gênero e o dia como horizonte temporal. Já se disse que Joyce, em Ulisses (1905), ao narrar "a vida cotidiana do mundo na unidade de uma só jornada concreta", retomava "a tradição literária do Ocidente desde a Ilíada e a Odisséia de Homero" 24.

Admitida essa tese, as preferências renascentistas pela narrativa de eventos diários constituiria mais um aspecto do retorno humanístico inclusive de Maquiavel - aos clássicos. Vários autores escreveram sobre o tema ${ }^{25}$. A atração pelo tempo breve, instantâneo é uma persistente linhagem da cultura ocidental. "O pensamento dos homens é o que, a cada dia, o Pai dos homens e dos deuses quer pôr neste mundo" 26 . A "força vital" dos homens determina, nessa tradição, a duração e as potencialidades da sua existência. É como se, em certos quadros históricos, e mesmo sempre, em regiões da nossa psique, não nos sentíssemos capazes de lidar com prazos longos. Nesse mundo temporalmente limitado, nesse mundo mortal, os homens não são capazes de conceber a história - senão de modo tentativo e obscuro - como sucessão de algum modo inteligível de eventos. Em sua faina cotidiana, eles não são estimulados à transcendência intelectual, mas apenas religiosa, através de sacrifícios, oferendas, rituais, festas, etc. Esse é o mundo dos heróis, dos bastardos semi-divinos, dos seres notáveis pela sua coragem e energia. Precariedade da vida, insegurança, laborioso enfrentamento dos desafios cotidianos, preeminência da coragem, da capacidade de comando, e do sentimento heróico de honra: seria excessivo tomar o mundo homérico como metáfora do mundo maquiaveliano?

23 Para uma interessante discussão sobre essa questão, ver Pocock, J. G. A., The Machiavelian Moment. New Jersey. Princeton University Press, 1975, cap. 1, pp. 3-9.

24 Sissa J. e Detienne, M. Os Deuses Gregos. São Paulo. Companhia das Letras, 1990, p. 16.

25 Starobinski, Fraenkel, Accane, mencionados por Sissa e Detienne, op. cit.

26 Ulisses, em Homero, The Odissey, Penguin, 1974, canto XVIII. Em outra passagem do mesmo canto: "De fato, a nossa maneira de ver o mundo aqui na terra depende inteiramente de como a Providência nos está tratando no momento"(p.279). 


\section{Homero, a tragédia e a ética aristotélica}

As aspirações de permanência de segurança, de ordenamento levam, necessariamente, à busca de uma orientação normativa para a vida comum. Essa busca se manifesta, em Homero, no culto aos deuses: na obediência a sua vontade, no afã de ganhar sua proteção e aplacar sua ira. No pantheon olímpico tal como projetado pela consciência religiosa da época, os deuses são eternos, isentos de preocupações e felizes, o que não impede que se imiscuam constante e apaixonadamente nos negócios de cá embaixo. O que se espera deles não são apenas benefícios individuais; nenhuma comunidade política, nenhuma cidade pode ser fundada e instituída sem ter deuses. O que se verifica, na religiosidade da época, é a intercessão entre o divino e o temporal. Movidos por inclinações, paixões e genealogias, imensamente preocupados pelo que aqui se passa, os deuses se fazem presentes em toda parte, a todo instante, e nisso exibem algo humano; favorecidos por eles, os homens participam, em certa medida, de sua natureza.

A decadência do Olimpo homérico tem a ver com esse modo de representar o divino. Platão dirá que "as maneiras e inclinações (dos deuses) não são dignas da perfeição que é inseparável da idéia de divino; Epicuro observa que o modo de vida passional (dos deuses), marcado pela inquietação, não é compatível com a certeza, natural entre todos os homens, de sua felicidade absoluta"27.

A tragédia grega do século V A.C. assinala, na tradição ocidental, a transição a uma ética secularizada e racional tal como exposta em Aristóteles. Vernant e Naquet analisam com brilho, erudição e detalhe essa evolução. De início, na tragédia, “o passado heróico parece muito próximo e muito novo para que se possa, sem risco, expo-lo em cena como espetáculo. No ponto final da evolução (...) a liame com a tradição é tão frouxo que não mais se sente a necessidade de um debate com o passado heróico. (...) (No homem de teatro), em seu público, em toda cultura grega, rompera-se a mola trágica"28. No seu auge, a ação trágica supõe "uma natureza humana que tem seus caracteres próprios e em que, em consequiência, os planos humano e divino sejam bastante distintos para oporem-se; mas é preciso que não deixem de aparecer como inseparáveis. O sentido trágico da responsabilidade surge quando a ação humana dá lugar ao debate interior do sujeito, à

\footnotetext{
27 Sissa e Detienne, op. cit. p. 21-2.

28 Vernant, J. P. e Vidal-Naquet, P. Mito e Tragédia na Grécia Antiga. São Paulo. Duas Cidades, 1977, pp. 14-5.
} 
intenção, à premeditação, mas não adquiriu consistência e autonomia suficientes para bastar-se integralmente a si mesma" 29 .

Em Aristóteles, a ação humana há de "bastar-se a si mesma", no sentido de orientar-se não mais por uma normatividade divina que se entrelaça na tragédia, com a responsabilidade do herói ${ }^{30}$, mas por uma ética secular e racional. Mais adiante (após a primeira aproximação de Maquiavel) apresenta-se um resumo da ética (e da política) aristotélica que, no argumento deste texto, dá o horizonte normativo da política maquiaveliana.

\section{Uma primeira leitura: a política do Príncipe como ação estratégica}

A descrição do contexto histórico em que surge e opera o Príncipe seria o ponto de partida de uma primeira leitura, dir-se-ia de raiz weberiana, de Maquiavel. Essa descrição seria uma etapa (o levantamento dos fatos e das circunstâncias) na construção de um tipo ideal de ação política individual orientada pela racionalidade instrumental. Não se trataria de uma ação com respeito a valores tradicionais, nem baseada no carisma. O objetivo estratégico da ação seria o de conquistar e manter o poder pelos meios mais adequados em cada conjuntura, quaisquer que sejam eles.

O apanhado de fatos e circunstâncias, realizado pelo próprio Maquiavel de forma sistemática em toda sua obra, poderia ser entendido, alternativamente, com esboço de elaboração de um sistema social total, articulando numa unidade conceitual de matriz funcionalista o conjunto das suas estruturas. O objetivo da reflexão de Maquiavel seria a CidadeEstado italiana, e não a ação política no contexto dessa Cidade. Adotando esse entendimento alternativo, fugiríamos da "leitura weberiana": estaríamos fazendo precisamente o que, segundo Parsons, Weber não fez $z^{31}$. Pode-se sustentar, porém, que os fatores históricos apontados por

29 Idem, p. 29.

30 Aristóteles, Problemata, 19, 48, cit. por Vernant e Vidal-Naquet, op. cit. , p. 32.

31 Parsons, T., Introduction a Weber, M., The Theory of Social and Economic Organization. New York. The Free Press, 1964, pp. 20-9. “A razão fundamental pela qual Weber suspeitava ênfase exagerada no enfoque funcionalista na ciência social estava na sua forte convicção da indispensabilidade, para se atingir um nível de conhecimento por ele considerado possível e essencial, de uma análise cuidadosa e detalhada da motivação do indivíduo. Para ele, partir do 'todo' cheirava a uma espécie de misticismo do qual seria possível derivar conclusões de grande alcance sem uma base empírica adequada, tirar coelhos da cartola funcional". Parsons entende, contudo, que é possível superar a "antítese" weberiana entre "o enfoque "funcionalista' e a análise dos motivos do indivíduo" (p. 20). 
Maquiavel dão a moldura de um sub-sistema de interações estratégicas em que cumpre idealmente aos agentes selecionar os meios adequados à maximização da sua utilidade política. Nesses termos uma primeira leitura, weberiana, permaneceria cabível.

Porque essa leitura é possível e tem sido feita ainda quando não se dá conta dos seus fundamentos teóricos?

Consideremos a seguinte passagem do Príncipe:

"Cesare Borgia era considerado cruel; no entanto, sua crueldade reformou a Romagna devolveu-lhe sua unidade e restaurou ali a ordem e a obediência. Bem pesadas as coisas, pode-se concluir que Cesare tinha mais compaixão que o povo florentino, que para evitar a pecha de crueldade, permitiu que Pistoia fosse devastada. (...) Entre todos os tipos de governantes, o novo príncipe é aquele que não pode evitar a reputação de crueldade, devido ao grande número de perigos que enfrenta num Estado recentemente conquistado"32.

Num primeiro momento, o novo príncipe aparece como um estrategista, escolhendo a cada momento entre ação implacável contra seus adversários e a compaixão ${ }^{33}$, entre "a lei e a força", entre a contemporização e o confronto, entre a astúcia e a coragem ${ }^{34}$, sua virtú, nessa primeira leitura, está em bem escolher os meios para acender ao poder e conservá-lo contra a "malignidade extraordinária e extremada fortuna"35. Trata-se de uma racionalidade prática, relativa aos meios de ação em situações particulares e de caráter puramente estratégico, pois que desvinculada de valores últimos ou universais de conduta humana nos planos privados ou público.

Maquiavel dissocia a política da moral - tal é a interpretação costumeira, e, de certo modo, verdadeira, com respeito às concepções prérenascentistas. Mesmo a unidade e a segurança do povo, "a ordem e a obediência" do povo, como na citação acima, seriam instrumentais com respeito ao objetivo de consolidação do poder do príncipe ${ }^{36}$. O pensamen-

32 Machiavelli. The Prince. op. cit., XVIII, p. 129.

33 A "compaixão" aparece aqui como um valor extra-político que, enquanto tal, não entra nos cálculos do príncipe - tanto é verdade que ele deve contar com a reputação de crueldade. Isso não impediria, é claro, que ele a utilizasse em seu jogo como lance racional. O próprio Weber admite que "não é suficiente considerar apenas o fato puramente formal de que cálculos são feitos por motivos utilitários. (...) Além disso, é necessário levar em conta o fato de que a atividade econômica é orientada para exigências de algum tipo. (Todos os padrões possíveis de valoração), contudo, são significativos apenas como bases a partir das quais se avalia o resultado da ação econômica"(op. cit. cap. II, 9, p. 185-6).

34 Essas oposições encontram-se, respectivamente nos capítulos XVIII, VII, do Príncipe e na Vita, op. cit., passim.

35 Idem, VII, p. 51.

36 "Não há porque tentar, nessa discussão (dos valores últimos), julgamentos de valor; cabe apenas determinar e delimitar o que se entende por 'formal'. Nesse contexto, o conceito 'substantivo' é ele próprio, num certo sentido, formal; isto é, é um conceito abstrato, genérico"(Weber, op. cit., cap. II, 9, p. 186). 
to do florentino articula-se aqui em torno da concepção ultra-realista da política como luta pelo poder tout court.

O significado do conjunto das ações do príncipe constitui um discurso legitimador: trata-se de uma legitimação por via das conseqüências de suas ações para o povo sob sua autoridade (e não por via da vinculação delas a valores tradicionais ou ético-políticos). Weber discutiu a possibilidade dessa ocorrência ao indicar que a legitimidade de uma ordem pode ser garantida ou sustentada "inclusive, ou inteiramente, pelo interesse próprio, isto é, através de expectativas quanto a consequiências ulteriores (das suas ações), conseqüências essas que são na verdade, de uma natureza particular"37. O príncipe não se pergunta se a lealdade ou apoio do povo se deve a crenças morais arraigadas, a costumes, ao reconhecimento do seu direito de governar ou às suas qualidades guerreiras - ou eventualmente pode até perguntar-se, valendo-se nesse caso da tradição, do afeto, da justificação racional ou da legalidade para reforçar o que ele bem sabe por experiência: o povo aspira à ordem, à segurança e à paz. E isso ele lhe dará sempre que for possível, consolidando assim seu principado.

Os "conceitos fundamentais" do pensamento sociológico de Weber (extensivo, é claro, à política) são definidos como segue pelo autor: a) objeto da Sociologia é a ação social individual; b) quanto ao seu status epistemológico, a Sociologia é uma compreensão interpretativa (da ação em questão) para chegar, por essa via, a uma explicação causal do seu curso e dos seus efeitos; c) a ação é social "na medida em que, em virtude do sentido subjetivo a ela associado pelo indivíduo (ou indivíduos) que age, leva em conta o comportamento dos outros e é portanto orientada no seu curso" 38 . As observações feitas até aqui permitem pensar que uma análise diretamente inspirada em Weber não seria muito diferente da análise que uma arqueologia interpretativa descobriria no próprio Maquiavel de $O$ Príncipe e da Vita. Weberianismo avant la lettre?

$\mathrm{O}$ conceito c) acima merece mais atenção. Também para Maquiavel a ação política se apresenta como subjetivamente significativa. Um leitor menos atento poderia entender o príncipe como um personagem essencialmente voluntarioso, como se sua luta cotidiana contra seus inimigos internos ou externos e contra toda sorte de adversidades se resumisse a um exercício solitário da sua vontade conquistadora. Não é assim. O príncipe, novo ou hereditário, habita um mundo de incertezas em que ele se

37 Idem, cap. I, 6, pp. 126-7.

38 Idem, cap. I, 1, p. 88. 
sente sempre ameaçado. Enfrentar adversários poderosos e angariar lealdades duráveis é para ele uma tarefa ao mesmo tempo, constante e de incerto resultado - mesmo porque ele é um inovador ${ }^{39}$. A virtú requerida de um príncipe envolve um número tão grande de qualidades - apontadas, uma a uma, por Maquiavel - que possui-las a todas raia o sobre-humano: sujeito às paixões e aos erros de cálculo, ele convive com a iminência do fracasso.

Que a ação do príncipe leve em conta necessariamente, nesse contexto, o comportamento dos outros, demostra o seu caráter estratégico que, a despeito da sua racionalidade ideal, é de alto risco. Se em Weber a influência de "fatores irracionais, como emoções e erros" 40 deve ser tratada como um desvio circunstancial com respeito ao tipo ideal do comportamento racional, em Maquiavel aqueles fatores irracionais são inerentes (como, de resto, e paradoxalmente, a racionalidade) à condição humana; eles são portanto elementos irremovíveis da análise de situações estratégicas particulares. O sucesso na biografia os príncipes - ou melhor dizendo o maior ou menor sucesso, atendendo a Skinner, para quem o único príncipe bem sucedido foi Francesco Sforza - deve-se não apenas à sua sabedoria prática como à sua boa fortuna, que por definição é imponderável. Na análise de uma campanha política ou militar, escreve Weber, "é conveniente determinar, em primeiro lugar, o que teria sido um curso racional de ação, dados os fins dos participantes e um conhecimento adequado de todas as circunstâncias. (...) Por comparação (com esse tipo ideal) é possível compreender o modo pelo qual a ação efetivamente em preenchida foi influenciada por fatores irracionais de toda sorte" 41. Em Maquiavel, a interveniência da fortuna torna impossível, por construção, o "conhecimento adequado de todas as circunstâncias" ligadas à ação. A não ser pela introdução da cláusula rebus sic stantibus, completamente estranha ao pensamento maquiaveliano, não seria portanto possível ver em $O$ Príncipe o esboço de um tipo ideal da ação política. Metodologicamente, os dois autores são de todo diferentes. Esse ponto será retomado adiante.

A despeito disso, diria o florentino, calcular é preciso. O príncipe deve decidir sobre o que fazer levando em conta sua finalidade, as circunstâncias e o comportamento esperado dos outros. A natureza estratégica do comportamento principesco evidencia-se, desde logo, na centralidade da dimensão militar da sua política: "Um príncipe não deveria ter outra finalidade ou pensamento, nem selecionar nada para seu estudo, que não a guer-

\footnotetext{
39 Pocock, J. G. A., op. cit., p. 167.

40 Weber, op. cit., I, 1, p. 92 .

41 Weber, op. cit., cap. I, 1, p. 92.
} 
ra, suas regras e disciplina; pois essa é a única arte que é própria do governante (...) "Armar-se, para o príncipe, não é apenas preparar-se para dar combate ao inimigo, o que para ele é inevitável, mas um meio para evitar o desprezo popular e para fazer-se obedecer no interior do seu próprio Estado"42. O militar subordina-se ao político. Em sua faina pelo poder, ele calcula permanente e essencialmente a reação de todos os demais agentes: os nobres, as facções, os reis, o papa, o povo e os chefes militares inimigos.

Assim se explica também a importância estratégica crucial, em Maquiavel, das aparências. Maior leniência interna em face de circunstancias adversas inesperadas não é aconselhável porque uma mudança que parece forçada por outrem não leva o povo a maior obediência ${ }^{43}$. Vários outros trechos ilustram esse ponto. "O príncipe deve cuidar para não parecer inconstante, frívolo, efeminado, mau caráter ou irresoluto (...) e mostrar grandeza, coragem, gravidade e força de espírito em suas ações (...) o príncipe que transmite essa impressão de si próprio é tido em alta estima, sendo portanto difícil conspirar contra ele (...)" 44 . E ainda: ser uma raposa é melhor do que ser um leão, "mas é necessário saber bem como disfarçar essa característica, e ser um mestre da camuflagem e do fingimento"45. Logo em seguida: "não é necessário que um príncipe tenha todas as qualidades que eu enumerei (compaixão, fé, humanidade, religiosidade, caráter) mas é muito necessário parecer tê-las. E eu ousarei dizer também que tê-las e sempre agir de acordo com elas é danoso, enquanto que parecer tê-las é útil" 46.

Esses exemplos são suficientes para demonstrar o caráter eminentemente estratégico da ação do príncipe. Dir-se-ia mesmo: exclusivamente estratégico, visto que o que ele faz enquanto tal é radicalmente separado do que ele poderia talvez fazer como cidadão comum orientado por suas crenças, tradições, valores ou quaisquer outros elementos da sua individualidade concreta, simplesmente humana.

\section{Uma segunda leitura: os fundamentos aristotélicos}

Prepara-se em seguida, para propor-se na seção seguinte, uma segunda leitura de Maquiavel, pela qual se refere à filosofia e à política

42 Machiavelli. The Prince, cap. XIV, p. 111.

43 Idem, cap. VIII, p. 69.

44 Idem, cap. XIX, pp. 145-6.

45 Idem, cap. XVIII, p. 138.

46 Idem, ib., p. 139. 
grega clássica. Essa segunda leitura não contradiz a primeira, mas a absorve num quadro mais amplo. O legado clássico nesta seção é representado pelo seu pensador mais importante, Aristóteles.

\section{Sobre o universal e o particular}

O estrategista trata da relação entre o temporal e o atemporal (o eterno) em conexão com o particular e o universal com categorias de uma teoria do conhecimento. A polis sob a forma de Cidade-Estado livre (depois denominada República) enquanto conceito - reemergente no humanismo cívico do século XV - "era ao mesmo tempo universal - no sentido de que existia para realizar para seus cidadãos todos os valores realizáveis para os homens nesta vida - e particular, no sentido de ser finita e localizada no espaço e no tempo" 47 . A teoria aristotélica da república é em boa parte, um esforço de reconciliação entre a instabilidade e desordem circunstancial da vida temporal (contingências) e a inteligibilidade das seqüências no plano da comunidade (o que constituiria, para Pocock, uma forma primitiva de historicismo).

Como vincular a "realização de todos os valores realizáveis", variáveis e de número indefinido, à idéia de bens universais? Na filosofia política aristotélica, o supremo bem - o que vale para todos os homens - é a justiça. Ora, a justiça política é em parte universal, em parte legal ou convencional. A justiça universal é natural - independe do que homens particulares pensem - e define-se por critérios racionais: "as constituições não são iguais, embora exista apenas uma que, por natureza, é em toda parte a melhor" 48 . "A melhor constituição é aquela que tem por finalidade o bem comum" 49 . Substantivamente, a justiça consiste na reciprocidade proporcional $^{50}$. Nas relações entre os homens, contudo, há quem "se atribui demasiado das coisas boas em si mesmas e excessivamente pouco das

\footnotetext{
47 Pocock, The Machiavelian Moment, p. 3.

48 Aristóteles, The Nicomachean Ethics, Oxford University Press, 1975, Livro V, cap. 7, p. 124. Também Aristóteles, The Politics, Penguin, 1992, p. 214. A edição aqui citada, com a mesma tradução da de 1962, tem introdução geral e introdução por capítulos de autoria diferente, alem de outras mudanças menores feitas na revisão. Tanto na Ethics como na The Politics são mencionados, nas citações abaixo, as referências numéricas às páginas, colunas e linhas do texto grego de referência (Aristóteles Opera, ed. por Beker, Berlim, 1831). Nas citações abaixo indicam-se o Livro em romanos, os capítulos em arábicos, e a(s) página(s). 49 The Politcs, V, 7, p. 214.

50 Ethics, V, 5, pp. 117-21. Por igualdade proporcional entende-se partes maiores para méritos maiores, e não partes iguais a cada um independentemente do mérito. Ver b) abaixo.
} 
coisas más em si mesmas". É por isso, diz Aristóteles, “que não admitimos que um só homem governe, mas princípios racionais" 51 .

Somente um homem de suprema virtude, porém, seria capaz de produzir a lei como Idéia ou Forma (no sentido platônico) ${ }^{52}$. Tal homem teria de ser considerado um deus, pois que tal conhecimento não é acessível aos homens. Por essa razão, "não deveríamos considerar tal homem como parte do Estado"; a lei não se aplica a ele mas "apenas a iguais em nascimento e capacidade" 53 . Estamos pois diante de duas alternativas: ou bem admitimos a possibilidade do conhecimento absoluto do bem comum (ou uma percepção metafísica dos supremos valores morais), independentemente, portanto, das circunstâncias em que ela se transforma em comandos justos (right rules) ${ }^{54}$ - e nesse caso o autor da lei deveria por princípio de justiça, exercer poder absoluto, legibus solutus, pois ele é a lei - ou bem abandonamos a esfera das Idéias e adotamos outras premissas sobre a natureza, alcance e as sequiências políticas do conhecimento racional.

Num primeiro momento, a razão se manifesta no ato de escolha - e toda ação refere-se a uma situação particular visando algo possível precedido por uma deliberação ${ }^{55}$. "Natureza, necessidade e fortuna são tidas como causas, mas também a razão e tudo o que depende do homem". $\mathrm{O}$ objetivo da deliberação são os meios, e não os fins ${ }^{56}$. Mas a razão instrumental é parte da racionalidade humana, e portanto não se confunde com ela. Também os fins, ou valores são racionalmente definíveis por quem possui virtude. Adotar os meios adequados à realização dos fins desejados pela virtude moral é objeto da sabedoria moral ${ }^{57}$. No plano político, a justiça "é a virtude completa em relação aos nossos vizinhos" 58 .

51 Ethics, V, 6, p. 122.

52 Pocock, op. cit. p. 20. Sobre o conceito de virtude, ver Politics introdução a III, 13, p. 209.

53 Politics, III, 13, p. 213.

54 Idem, introdução a III, 13, p. 210.

55 Ethics, III, 1, pp. 52-3; III, 2, p. 52-4.

56 Idem, III, 3, pp. 55-6. Esse trecho de Aristóteles tomado isoladamente pode fundamentar a "primeira leitura" de Maquiavel; ele apoia também a interpretação da fortuna como dimensão constitutiva da ação do príncipe, e não como "fator acidental", como na interpretação weberiana. A reflexão aristotélica fica bem clara nos seguintes trechos: "As ações pertencem à classe dos particulares". Quando ações particulares são voluntárias, é muito difícil estabelecer "que tipos de coisas devem ser escolhidas, e que tipo de benefício se espera delas (...) pois há muitas diferenças entre os casos particulares (Ethics, III, 1, p. 50). Ações voluntárias: nelas "o princípio ativo é o agente que é conhecedor das circunstâncias particulares da ação"(Idem, III, 1, p. 52). "A escolha não se refere, em sua finalidade, aos impossíveis" (com exceção do desejo de imortalidade), (Idem, III, 2, p. 54).

57 Idem, VI, 12, pp. 154-5.

58 Idem, V, 1, p. 155 


\section{Sobre as virtudes morais}

Vale a pena expandir um pouco mais o conceito de virtude no quadro da filosofia moral de Aristóteles para melhor fundamentar o argumento da seção abaixo sobre a "segunda leitura" de Maquiavel. Seria ocioso, de resto, lembrar a enorme e duradoura influência dessas reflexões no pensamento ocidental.

Essa discussão remete, em última instância ao estatuto metafísico da forma em Aristóteles, como já indica em a) acima. Em Platão, conhecer a Forma de $x$ é entender a natureza de $x$. Apreender a Forma da justiça significa não apenas saber que atos são justos mas também porque são justos, independentemente da variedade dos atos justos. A forma em Aristóteles é também o que torna algo inteligível; aqui, como lá, a forma é racionalmente apreendida. Mas a forma aristotélica não tem existência separada, independentemente. O que existe com independência é a substância, e esta consiste em forma e matéria. A matéria é aquilo que tem forma, e a forma é o que torna a matéria inteligível. A experiência homérica do divino aparece aqui como metáfora de uma metafísica do real.

Esse posicionamento básico manifesta-se no campo da filosofia moral ${ }^{59}$, onde se passa da intuição racional dos primeiros princípios à deliberação política que precede a ação voluntária individual (decreto) ${ }^{60}$ ou, mais precisamente, às deliberações ou escolhas voluntárias à respeito de ações particulares envolvendo fins (aquilo que é bom para os homens) e meios adequados à sua realização ${ }^{61}$.

Ora, "a ciência do que é bom para o homem é a política": Aristóteles abre a Ética com essa afirmação. As ações e empreendimento que visam algum bem são manifestações da virtude. Os bens são manifestações da virtude. Os bens se hierarquizam segundo sua qualidade, ou importância. O bem supremo é aquele que se deseja em si mesmo, não em função de outras. Tal é o bem do Estado. A reflexão sobre o exercício da virtude culmina na realização desse bem como objeto de uma arte - a maior das artes - que é a arte política ${ }^{62}$. Trata-se de uma arte, e não de puro exercício racional: a arte tem como objeto o fazer com base num curso verdadeiro da razão63.

\footnotetext{
59 Idem, I, 6, pp. 7 a 9.

60 Idem, VI, 8, p. 147.

61 Idem, III, 1 a 6 , passim.

62 Idem, I, 1, p. 1.

63 Idem, VI, 5, 142.
} 
Na distinção clássica, a virtude pode se moral ou intelectual ${ }^{64}$. A "natureza específica" da virtude, que torna os homens bons e capazes de realizar bem o seu trabalho, é a disposição de caráter que leva a escolher a média, ou ainda, a evitar os excessos ${ }^{65}$. A coragem é o meio termo entre o medo e o excesso de confiança; a temperança evita os excessos da autoindulgência e a insensibilidade. A média também é a differentia das outras virtudes: liberdade, amor próprio, ambição, bom temperamento, amistosidade, veracidade, humor, tato e, em particular, a virtude da justiça, tanto distributiva quanto compensatória. Até que ponto um homem pode desviarse da média sem ser culpabilizado depende das circunstâncias particulares; esse patamar não pode ser racionalmente determinado ${ }^{66}$.

A virtude moral se adquire pelo hábito. Ela se manifesta em ações voluntárias, ou seja em, ações não praticadas sob compulsão, que envolvem conhecimento das circunstâncias e, em especial, que resultam de uma escolha após deliberação previa ${ }^{67}$. A deliberação diz respeito aos meios, não aos fins, e concerne o que pode ser feito. Como o próprio nome indica, a deliberação é racionalmente orientada, e compõe a virtude: "a virtude é um estado de caráter que concerne a escolha de uma média relativa a nós, sendo essa escolha determinada por um princípio racional e pelo princípio segundo o qual o homem dotado de sabedoria prática a determinaria" 68 .

Como já indicado, a ação virtuosa tem também em vista uma finalidade, e esta não pode ser objeto de deliberação. A finalidade da ação é objeto do desejo racional. Ao que parece, Aristóteles dá-se conta da dificuldade dessa posição. Como justificar, aqui, o uso do adjetivo racional se diferentes coisas parecem boas a diferentes pessoas? A resposta é hesitante: "cada estado de caráter tem suas próprias idéias sobre o que é nobre e agradável, e talvez o homem bom (virtuoso) difira dos outros sobretudo porque vê a verdade em cada classe de coisas, sendo por assim dizer a sua norma e medida" ${ }^{69}$. $\mathrm{O}$ argumento parece ser um tanto ilógico: as ações virtuosas são aquelas que (ademais de escolha de meios) se originam do desejo do verdadeiro bem, que é próprio dos homens virtuosos. De modo algo mais formal:

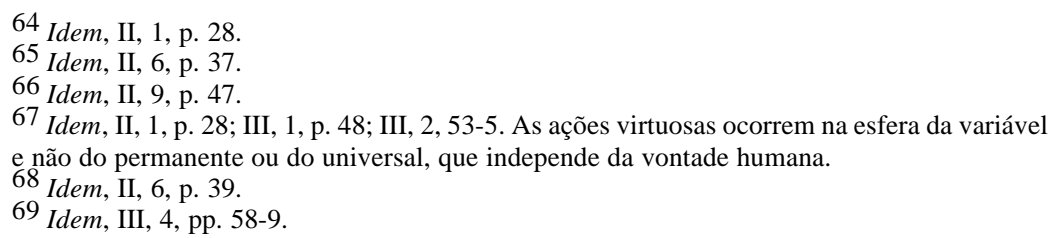


1. Primeira proposição: sou virtuoso devido ao meu hábito de desejar racionalmente o bem. Esse hábito é a causa eficiente da minha virtude; ele é um dado, não se explica senão pela experiência de vida ${ }^{70}$.

2. Segunda proposição: desejo o verdadeiro bem (desejo racionalmente o bem) porque sou virtuoso.

Dificuldades: na primeira proposição, a causa eficiente é um dado, uma ocorrência. Mas "as virtudes não nos vem da natureza ou do que é contrário à natureza". Nós apenas somos naturalmente capazes a recebe-las e as adquirimos na medida em que as exercitamos ${ }^{71}$. Nesse sentido seríamos nós mesmos os autores da nossa virtude.

Na segunda proposição: "ser virtuoso" parece ser um dado enquanto causa eficiente. Mas isso não é possível, pelas razões acima.

A solução para essa aparente tautologia pode ser a seguinte: "virtude" e "desejo racional do bem por hábito" são uma e a mesma coisa. São ademais, a causa final em busca de uma causa eficiente que não se encontra nas duas proposições acima. Essa causa eficiente é política: é a boa constituição: "(o argumento desenvolvido até aqui) é confirmado pela observação do que ocorre nos Estados em que os legisladores tornam os cidadãos bons através da formação de bons hábitos neles, e esse é o desejo de todo legislador; aqueles que não fazem isso erram de alvo, e é nisso que uma boa constituição difere de uma ruim"72. A origem da minha virtude não está na natureza, nem em mim individualmente; está no bom ordenamento político da comunidade. A virtude de um homem requer a virtude dos demais.

Pois bem: o supremo bem na virtude política - aquilo que se deve desejar em si mesmo - é a justiça (como já referido acima), ou “o estado de caráter que predispõe o homem a fazer o que é justo a agir com justiça e a desejar o que é justo". A justiça manifesta-se externamente como acatamento da lei e da equidade ${ }^{73}$. As ações praticadas de acordo com as disposições do legislativo segundo a justiça são portanto justas, e aquelas disposições visam vantagens comuns a todos, aos melhores ou aos que governam. Visam portanto a felicidade da sociedade política. As leis nos solicitam a praticar ações virtuosas e a condenar as más. Ao obedece-las, praticamos todas as virtudes; nesse sentido, a justiça é a "virtude comple-

70 Idem, II, 1, p. 28.

71 Idem, $i b$.

72 Idem, II, 1, p. 29.

73 Idem, V, 1, pp. 106-7. 
ta, a maior das virtudes, que se exerce não só com relação a nós mesmos como com relação ao nosso vizinho". Buscar o bem do outro: tal é a differentia da justiça entre as virtudes tomadas em seu conjunto ${ }^{74}$.

Note-se, porem, que ser um homem de virtude não eqüivale, senão idealmente, a ser um bom cidadão. $\mathrm{O}$ bom cidadão conforma-se à lei mesmo que coagido a faze-lo, e a lei tem poder coativo sobre os "muitos" que não tem hábitos virtuosos e não são permeáveis a argumentos. $\mathrm{O}$ uso da força nesse caso é uma dimensão da virtude legislativa (statemanship $)^{75}$.

O que foi dito acima sobre a justiça vale tanto para a justiça universal - aplicável a todas as questões humanas - como para a justiça particular. Esta se manifesta como equidade e igualdade (não como correspondência à lei) e pode ser distributiva ou retificadora. A primeira diz respeito à distribuição de honrarias e bens materiais entre os membros da comunidade política. A equidade consiste em distribuir tais benefícios segundo o mérito de cada um; a equidade promove a igualdade em termos de distribuição proporcional, não igualitária. A segunda também visa a igualdade, sendo esta aritmética e não geométrica. Trata-se de retificar os danos causados por um homem sobre outro, considerando-se a ambos como iguais independentemente do mérito ou da virtude de cada $u^{76}$.

Também pertence à justiça retificatória o princípio da reciprocidade, tratado no livro V, 5. O princípio refere-se ao retorno ou compensação equivalente nas trocas. E essa equivalência que "mantém a sociedade coesa". Como se sabe, Marx vê nessa passagem uma formulação da teoria do valor de troca: os bens são transacionados segundo o tempo de trabalho necessário à sua produção. Aristóteles não menciona de modo explícito o " tempo de trabalho", embora essa categoria possa estar implícita no texto; o dinheiro como equivalente universal, por sua vez, é explicitamente mencionado.

Tratando especificamente, e mais um vez, da justiça política, Aristóteles afirma que a ação injusta de uma pessoa não implica que ela seja injusta. O exemplo é o de um homem (eventualmente justo) que comete adultério por paixão e não por deliberação. $\mathrm{O}$ argumento prepara a

74 Idem, V, 1, p. 7-8.

75 Idem, X, 9, pp. 272 a 274 . O mesmo argumento, na Política, desenvolve-se de maneira algo diversa, apontando Aristóteles para o dilema entre ser bom cidadão e ser um bom homem. Os homens são destinados a utilizar suas faculdades, sobretudo a mais nobre, a intelectual. Mas um homem deve renunciar a essa utilização na medida em que é chamado a obedecer as leis quer ele as prove, ou compreenda racionalmente, ou não; dessa forma, o cidadão comum não pode ser um bom homem. Apenas os governantes, tendo aprendido, enquanto governados, os princípios da política, podem ser ao mesmo tempo virtuosos e bons cidadãos (Política, III, 4, pp. 179 a 183, e a introdução ao capítulo, p. 178).

76 Idem, V, 2, pp. 3-4. 
tese de que não é o homem que deve governar, mas um princípio racional, tal como já apontado antes neste trabalho. $\mathrm{O}$ homem está exposto às paixões que o impedem de agir racional ou deliberadamente, e em virtude disso pode tornar-se um tirano ${ }^{77}$. O que se deve entender por "princípio racional", que dá fundamento ao desejo de fazer o bem - no caso, de promover a justiça? É o princípio que recomenda o atendimento aos dois requisitos da promoção da justiça. O governante deve atentar para o fato de que " a justiça política é em parte natural, em parte legal. É natural naquilo que tem a mesma força em todo lugar, e não depende das pessoas pensarem isso ou aquilo". A justiça legal é convencional: "as constituições não são por toda as partes as mesmas"78. Mas a distinção não é meramente analítica: "o justo relaciona-se ao legal como o universal ao particular"79.

Não obstante, tanto a justiça natural como a legal são variáveis, cambiantes de lugar a lugar ${ }^{80}$. Pode-se interpretar isso da seguinte maneira: mesmo a justiça natural manifesta-se em ações concretas, que variam segundo as circunstâncias. A natureza das coisas não tem existência ideal independente, embora a razão possa discernir, em cada substância, o universal e o particular. É possível a partir da formulação de uma norma da justiça universal, por exemplo, tentar verifica-la e justifica-la nas relações concretas entre os homens. Por outro lado, a justiça legal pode aproximarse, por variações sucessivas, da forma racional, na medida em que a legislação reflita a tendência inerente aos governantes virtuosos de desejar o verdadeiro bem. Essas observações introduzem a questão da relação entre virtude moral e intelectual, sobre a qual se dirá algo mais abaixo.

O problema da atualização do universal nos caso particulares em que se requer um decisão referida a critérios de justiça surge, mais uma vez, na discussão da equidade - entendida aqui como estado de caráter que permite ao homem justo enfrentar "um caso não coberto pela disposição legal universal" 81 . Supõe-se, aqui, que "o legislador errou por excesso de simplicidade"; seria talvez, possível dizer que errou por excesso de universalidade, ao conferir à norma geral um grau indevido de independência com respeito ao mundo real. Tal é a natureza da equidade: um correção da lei onde ela é insuficiente devido à sua universalidade. A norma de

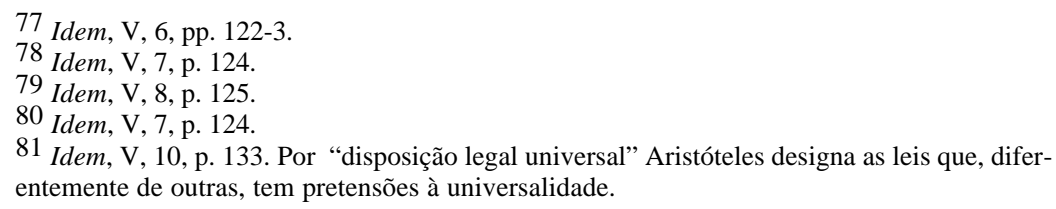


equidade é objeto de um decreto adaptado aos fatos ${ }^{82}$. Essas observações também ajudam a compreender a possibilidade de variação da justiça natural em Aristóteles, acima aludida.

\section{As virtudes intelectuais}

As virtudes intelectual consiste no exercício da razão em sua várias modalidades. Cada uma dessas modalidades produz um certo tipo de sabedoria, isto é de conhecimento do que é verdadeiro e bom para os homens. "A sabedoria é a mais acabada das formas de conhecimento", disso se conclui que "o que decorre dos primeiros princípios, mas também a verdade dos primeiros princípios. A sabedoria, portanto, tem de ser razão intuitiva combinada com o conhecimento científico dos mais elevados objetos". A sabedoria filosófica é a principal virtude intelectual: é a sabedoria "do homem sábio em geral, e não do sábio em alguma área particular"83.

Essas proposições envolvem a distinção entre a sabedoria filosófica (combinação de intuição dos primeiros princípios com as sua demonstração científica) ${ }^{84}$ e a sabedoria prática, que torna possível "bem deliberar sobre o que é bom e útil para si mesmo, não com respeito com respeito a bens particulares (como a saúde ou a força), mas com respeito ao que conduz à boa vida em geral" 85 .

A sabedoria aplicada à cidade envolve dois tipos de sabedoria: prática e política, que correspondem ao mesmo estado de espírito, mas são em essência diferentes. Se o objeto é a cidade "a sabedoria prática que tem o papel de controle é a sabedoria legislativa; a que se refere às leis como particulares em relação a seu universal é a sabedoria política ${ }^{86}$.

A finalidade da sabedoria filosófica é distinguir o verdadeiro do falso. A sabedoria prática fundamenta a boa escolha como combinação do desejo e do uso da razão. Essas duas virtudes intelectuais são independentes uma da outra. Há homens que tem sabedoria política e não prática, “como Anaxágoras e Tales", em outros, como Péricles, dá-se o inverso ${ }^{87}$.

82 Idem, V, 10, passim.

83 Idem, VI, 7, passim.

84 Idem, VI, 6, p. 144.

85 Idem, VI, 5, p. 142.

86 Idem, VI, 8, p. 147

87 Nem na Ética nem na Política Aristóteles afirma a superioridade de uma sobre outra. Na Politics, em especial perguntando-se "que tipo de vida é preferível, a vida de participação nos trabalhos do Estado e de constituição ou a vida separada do Estado?" Aristóteles diz: essa questão (a questão da preferência entre a vida ativa e a contemplativa) diz respeito ao indivíduo (e não pode, ao que se depreende do texto ser racionalmente resolvida). (Politics, VII, 2, pp. 395-8). 
Isso não significa, porem, que a sabedoria prática em geral e a sabedoria política em particular possam prescindir do conhecimento do universal como uma das condições da boa escolha. Mas "a sabedoria prática não se preocupa apenas dos universais; ela tem também de reconhecer os particulares" 88 . O universal em política é o que seria escolhido por homens perfeitamente bons do melhor para a comunidade entre todos os bens alcançáveis pela ação humana. Na sabedoria política, as virtudes morais e intelectuais entrelaçam-se ${ }^{89}$.

$\mathrm{O}$ "melhor" entre as alternativas políticas possíveis, o supremo bem da comunidade é a boa constituição, na qual os membros podem ser bons cidadãos: unir-se para o bem comum e para a preservação da constituição, pois que tal é a virtude do cidadão ${ }^{90}$.

\section{Os cidadão aristotélicos}

Os membros da polis, ou comunidade política são cidadãos. Dela não fazem parte, desde logo, as mulheres e os escravos, por razões que não nos cabe discutir aqui. Ầ parte isso, não são cidadãos os que simplesmente residem na cidade; nem se adquire a cidadania pela mera posse de direitos decorrentes de contratos comerciais, como o direito de processar a outrem na justiça. Os direitos característicos do cidadão, sugere ele, são direitos políticos: o de ocupar cargos públicos, de participar das decisões públicas e de participar da administração de justiça ${ }^{91}$.

Como "ocupar cargo público" significa tanto exercer cargo no governo como ser membro de uma assembléia popular, a característica essencial do cidadão não é o exercício de uma função pública permanente, mas o direito de participação nas funções de deliberação e administração da justiça.

O conceito aristotélico de cidadão é descritivo: alguns são cidadãos (tem direitos políticos) sem que devessem sê-lo. Mas quem ao mesmo tem é e merece ser cidadão? A resposta a essa questão encontra-se

88 Idem, VI, 7, p. 146.

89 Segundo um comentador, "alguns cientistas políticos modernos sustentariam que a discussão sobre valores e ideais humanos deveria ser evitada. (...) Julgamentos de valor, afirmase, são matéria de escolha ou preferência, não conhecimento. Aristóteles, no entanto, não aceita de modo algum essa nítida distinção lógica entre fatos e valores. Ele acredita em que se pode ter conhecimento e estar certo ou errado, nas questões concernentes a valores" (Mulgan, R. G., Aristotle's Political Theory, Clarendon Press, Oxford, 1977, p. 9.

90 Politics, III, 4, pp. 179-80.

91 Politics, III, 1 a 3, pp. 167-76. Para umas interessantes discussões dessas questões ver Finley, M. I., Democracy Ancient and Modern, Londres, 1973, esp. cap. I; Mulgan, R. G., "Aristotle and de Value of Political Participacion" in Political Theory, 18, 1990, pp. 195-215. 
no que foi dito acima. O conceito de "cidadão virtuoso" acrescenta à definição descritiva da cidadania uma dimensão normativa indispensável.

\section{MAQUIAVEL E A BOA ORDEM: Uma nova leitura de Maquiavel}

Na seção 6 sustenta-se que a fortuna maquiaveliana tem efeitos inescapáveis, negativos ou positivos, sobre os resultados da ação política. Por essa razão não se poderia ver no Príncipe a construção de um tipo ideal de ação política racional eventualmente alterada por erros ou paixões. Admitir isso invalida desde logo uma aproximação metodológica entre o florentino e Weber.

Desenvolvendo o argumento, questiona-se também a interpretação, apurada em bons argumentos e em várias passagens de $O$ Príncipe (citados acima), segundo a qual a "ordem" e a "paz" seriam valores excessivamente abstratos ou indeterminados para que se pudesse identificar neles uma dimensão ética constitutiva da política maquiaveliana. No máximo poderiam aparecer como elementos formais - correspondentes a toda e qualquer preferência normativa dos indivíduos - num esquema interpretativo que se concentra na racionalidade instrumental da política.

Uma leitura weberiana de Maquiavel, dir-se-ia, é de alcance limitado na medida em que se os dois autores divergem, em última e decisiva instância, no plano de teoria do conhecimento da sociedade. Em Weber, o sentido subjetivo da ação, tal como teoricamente determinado no tipo ideal, "não se refere em nenhum caso a um sentido objetivamente 'correto' ou a um sentido ‘verdadeiro’ em alguma acepção metafísica"92. Maquiavel, pelo contrário, à maneira de Aristóteles, refere a ação política a valores cuja validade é racionalmente demonstrável. A sociologia weberiana é axiologicamente neutra: é uma "ciência empírica" que busca "uma compreensão interpretativa (da ação individual) para chegar, por essa via, a uma explicável causal do seu curso e dos seus efeitos". A ação política em Maquiavel tem uma dupla dimensão: a estratégica, que diz respeito aos meios utilizados e a substantiva, posto que envolve um reflexão sobre seus fundamentos éticos (ainda que o próprio Maquiavel não tenha exposto de maneira explícita, em texto próprio, a normatividade que permeia seu pensamento). Tal é o argumento a ser justificado nesta seção.

92 Weber, op. cit., cap. I, 1, p. 89. 


\section{A virtú do príncipe}

Nessa discussão é preciso ampliar a bibliografia maquiaveliana, somando ao Príncipe e a Vita os Discorsi e a Arte della Guerra. A ênfase temática se desloca. O tema central da virtú é um ponto de partida adequado ao conjunto do argumento.

Como sugerido acima, o Príncipe e a Vita podem sustentar, numa primeira leitura, duas interpretações da virtú. Na primeira, ela se decomporia num número tão grande de qualidades particulares que tê-las a todas seria impossível para um simples mortal. Entre essas qualidades incluem-se coisas tão dispares como "liberdade" e "capacidade de parecerse o que não se é”. Na segunda, todas essas qualidades particulares seriam vistas como meios para a conquista e manutenção do poder: a virtú consistiria na capacidade estratégica do príncipe permanentemente ameaçado por inimigos e às voltas com os caprichos de fortuna, ou seja, na capacidade de bem escolher seu curso de ação em face da ação prevista dos outros. Nesse caso, sua virtude seria medida pelo sucesso maior ou menor de sua empreitada política. O príncipe virtuoso é um mestre da estratégia e do curto prazo. Ele se legitima ou não, a posteriori, pelos resultados, positivos ou negativos da sua ação.

Nos Discorsi e na Arte descortina-se de maneira mais explícita uma terceira acepção do termo: virtú é a capacidade, tanto dos governantes como dos cidadãos, de referir sua ação a valores republicanos, que são universais no campo da política ${ }^{93}$. Mas esses valores só se realizam no enfrentamento dos desafios específicos de cada situação. Essa leitura remete Maquiavel à sua matriz aristotélica, e pode estender-se também ao Príncipe e a Vita.

Toda a obra de Maquiavel situa-se no universo cultural do "humanismo cívico", próprio do Renascimento italiano a partir do século $\mathrm{XV}$, ou pouco antes. Vivia-se, então, o "fim das trevas"; revalorizava-se os valores clássicos (Aristóteles, Sêneca, Cícero) inclusive o da liberdade como ausência de coerção ou limitação externa de qualquer tipo, e em espe-

93 No último capítulo de $O$ Príncipe, em que Maquiavel dirige-se diretamente a Lorenzo de Medici, lê-se: "Tendo considerado o tema dos discursos acima, e perguntando-me se os tempos presentes são propícios a um novo príncipe, e se esse tempo daria a um príncipe sábio e virtuoso a oportunidade de introduzir uma nova ordem que traria glória a ele e o bem do povo deste país, parece-me (que nunca houve tempo mais propício)” (The Prince, cap. XVI, p. 205). 
cial, política ${ }^{94}$. Nesse contexto, afirmação de Maquiavel: “o povo não deseja ser oprimido pelos nobre" 95 ganha uma nítida conotação republicana.

O príncipe "deve tratar amistosamente o povo", e só deve usar de severidade quando sua segurança é ameaçada ou quando dela resultar benefícios para os cidadãos; caso contrário a severidade levará à sua queda ${ }^{96}$. Essa passagem também pode ter um entendimento republicano, e não estratégico. A regra, para o príncipe virtuoso, é sintonizar-se tanto quanto possível com o povo, sendo sempre atento a suas demandas e aspirações. Castruccio Castracani em seu leito de morte diz a um seu amigo: "Eu não deveria ter subjugado Pistoia, nem ultrajado os florentinos. Eu deveria, antes, ter angariado a amizade desses dois povos, (...) deixando-os um Estado sem dúvida menor, porem mais seguro e assentado sobre uma fundação mais segura" 97 .

O trecho acima reintroduz a questão do tempo em Maquiavel no contexto do presente argumento. O príncipe confrontado às reviravoltas da fortuna é o estrategista do curto prazo. Mas o príncipe que aspira a uma ordem estável deve legitimar-se no longo prazo, seja respeitando a tradição de liberdade ("nas repúblicas há mais ódio e desejo de vingança; a memória de sua antiga liberdade não deixa o povo em paz") ou inovando com boas leis (entenda-se: leis da liberdade). A virtú do estrategista não é a mesma do legislador. No Príncipe o "Estado seguro" é obra de um condottiere que pode tornar-se num legislador. No Discorsi "nós nos deparamos tanto com o líder militar que funda uma república como a própria república como hegemônicos"98.

O poderio militar requer virtudes cívicas. A força de Roma repousava na mobilização de um máximo de virtú para fins tanto militares como cívicos. Essa é uma das maneiras de entender a passagem do principado à república ${ }^{99}$, e a integração da virtude humana à virtude cívica: contrariamente ao que sustentou Aristóteles, a primeira (no caso, a coragem e a disciplina) não se adquire sem a segunda (o amor à Pátria). A virtude se politiza no sentido de ser tanto um atributo do bom governante (do bom legislador) como de dever-se estender a todos os cidadãos.

No pensamento humanístico do Renascimento italiano, "honra, fama e glória", de uma parte, e "sabedoria e virtude", de outra, são

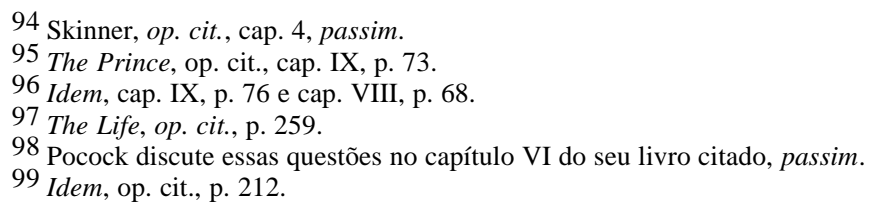


maneiras de apresentar os referentes últimos do fazer político. Ambas procedem da revalorização da razão prática na vita activa no final dos trecento e nos quattrocento, em confronto com a primazia escolástica da vita contemplativa, e ambas estão presentes na obra de Maquiavel.

A "sabedoria e virtude" politizadas realizam-se na republicanização da Cidade por via da educação cívica na moldura institucional criada por boas leis. A mensagem a Lorenzo de Medici e a autocrítica de Castracani, citadas acima, aludem à boa ordem como horizonte normativo da política. Pocock desenvolve a questão na análise que faz do príncipe como inovador a partir do capítulo VI do Príncipe, onde se lê: " $(\mathrm{O}$ príncipe) que depende menos da fortuna do que da virtude se estabelece de maneira mais segura (...). Mas para falar agora dos que, por sua habilidade e não pela fortuna, subiram à posição de príncipe, digo que Moisés, Ciro Rômulo, Teseu e outros são excelentes exemplos. Moisés era um executor da vontade divina, e por essa razão não pode ser discutido, embora deva ser admirado quando menos por ser merecedor da conversação com Deus. Mas considerando-se Ciro e outros que adquiriram ou fundaram reinos, todos são admiráveis, e se considerarmos seus feitos particulares e sua conduta, veremos que não são inferiores aos de Moisés, embora este último tenha tido tão grande preceptor. E examinando suas ações e vidas, vemos que eles não deveram a fortuna senão a oportunidade, que lhes deus a matéria à qual deram a forma que lhes parecem melhor. Sem aquela oportunidade, seus poderes intelectuais ficaram sem uso; e sem aqueles poderes a oportunidade se ofereceria em vão"100.

Logo em seguida, esses príncipes são chamados de "inovadores" e "profetas", e não de "novos príncipes", e observe que só são bem sucedidos os "profetas armados"; os desarmados, como Savanarola, "não teriam conseguido manter suas constituições em visar por muito tempo". O inovadores são fundadores de reinos, como Licurgo em Esparta (a quem Aristóteles chama de "legislador"). São reinos viáveis e seguros. O príncipe, como espécie do gênero "inovador" funda um stato no sentido de "poder de alguns sobre outros" (Gicciardini e Maquiavel). Tal poder constituirá a "segunda natureza" dos homens, ou ainda, reconduzirá a comu- 
nidade política à sua prima forma e os homens à sua verdadeira natureza, definida como tendência ao bem comum ${ }^{101}$ e à liberdade das repúblicas ${ }^{102}$.

A intervenção no plano do stato desestabiliza o povo e provoca a hostilidade dos nobres, expondo o príncipe aos azares da fortuna. De início, toda nova ordem é uma formação política precariamente legitimada. Pois bem: a 'virtú' dos inovadores mencionados está justamente em criar as condições políticas propícias à substituição dos egoísmos florescentes sob a tacão dos poderosos por uma ordem republicana (no sentido aristotélico e humanístico de ordem referida ao bem comum).

A elaboração maquiaveliana dos dois aspectos da virtú acima discutidos a partir do conceito de inovação no Príncipe pode ser esquematizado como segue:

O humanismo maquiaveliano e a dignidade humana

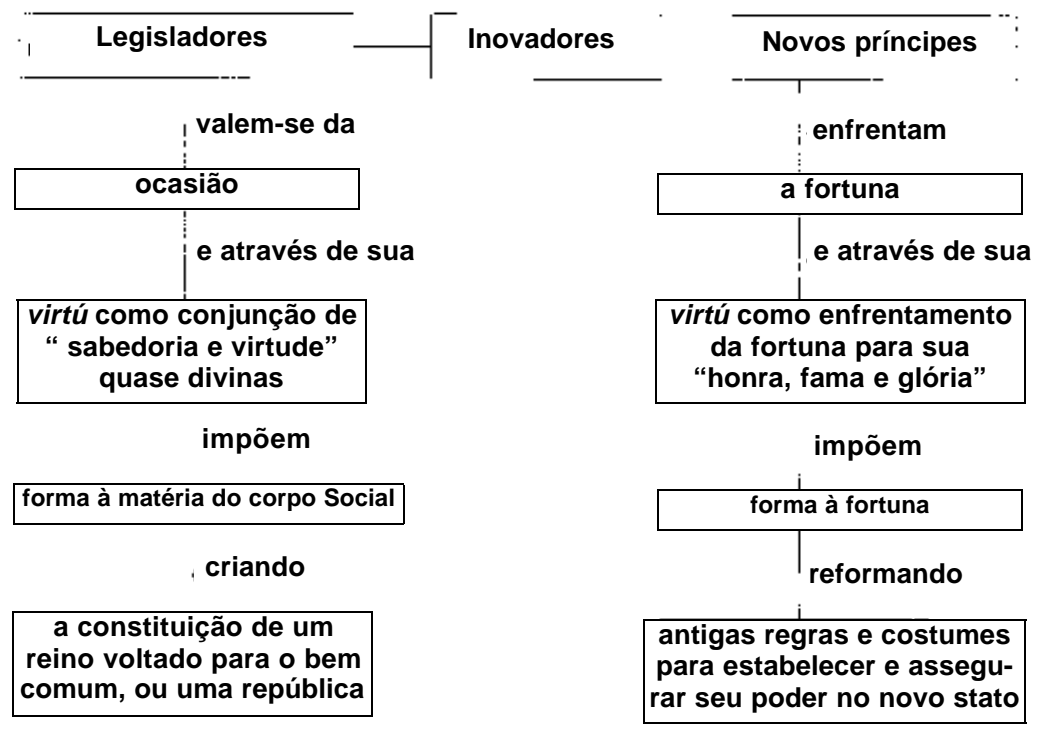

101 Guicciardini, Dialogo e Discorsi del Regimento di Firenze, Laterza, Bari, 1932, cit. por Pocock, pp.136 e passim no cap. V.

102 Mais uma vez: “Aquele que se tornou senhor de uma cidade acostumada à liberdade (e não respeita essa liberdade) ou a destrói ou pode esperar ser destruído por ela, que se unificará na rebelião em torno da liberdade e dos seus antigos privilégios, os quais nem o tempo os favores recebidos do novo senhor farão esquecer". Nas repúblicas dominadas persiste a memória da antiga liberdade, (The Prince, cap. V, p.38). Ver também Comentário ... p. 105, nota a), bem como as observações de Skinner, cap. 3 e Pocock, op. cit., pp. 208-9). 
“(...) Ceci veut dire aussi qu'on ne dépasse le monde qu'en y entrant et que, d'un seul mouvement, l'esprit use du monde, du temps, de la parole, de l'histoire et les anime d'un sens qui ne s'use pas"103

Uma leitura inspirada em Merleau-Ponty agregaria ao humanismo cívico italiano e em especial à existência fracionada do príncipe uma outra dimensão da tradição humanista ocidental: a que toma o homem como tensão entre o sonho de um espírito eterno e o mundo vivido da interação temporal real, verdadeira. As incertezas irredutíveis da fortuna dissipam a magnífica prevenção a tomar o mundo como pura objetividade redutível a um ser externo a nós e, portanto, a formulas metafísicas ou receitas canônicas. A fortuna, mais do que as "paixões" aristotélicas, nos remete, sem retorno, ao mundo da intersubjetividade que por definição envolve intransparência: vivemos "une eternité manquée". O príncipe, como o filósofo merleau-pontiano "é o movimento que reconduz sem cessar do saber à ignorância, da ignorância ao saber, e uma espécie de repouso nesse movimento"104.

Num outro ensaio, o filósofo refere-se diretamente ao humanismo do florentino: "Se denominamos humanismo uma filosofia do homem interior que não encontra nenhuma dificuldade de princípio nas suas relações com os outros, nenhuma opacidade no funcionamento social e substitui a cultura política pela exortação moral, então Maquiavel não é humanista. Mas se denominamos humanismo uma filosofia que problematiza a relação do homem com o homem e a constituição entre eles de uma situação e de uma história comuns, então é preciso dizer que Maquiavel formulou algumas condições de todo humanismo sério"105. Fazer política é relacionar-se com os outros, e não apenas com princípios; a história é conflituosa, acompanhando-se, não obstante da inquietude inaplicável que aspiração de "boa ordem" - da "clarté politique" - nos traz. Diríamos também, em chave habermasiana, que a política é ou requer a ação comunicativa, que visa e pode gerar um consenso razoável, mas que se obscurece ou se interrompe sob o impacto das desigualdades de poder e de dinheiro.

A ciência maquiaveliana é dolorosa, quase insuportável; poderia ter sido diferente na Itália dilacerada do seu tempo? E poderiam os homens em luta reconhecer-se no que têm em comum - uma situação, uma história,

103 Merleau-Ponty, M., "Eloge de la Philosophie" in Eloge de la Philosophie. Paris. Gallimard, 1960 , p. 15.

104 Idem, p. 11.

105 Merleau-Ponty, M., "Note sur Machiavel”. op. cit., p. 376. 
um futuro arriscado - e constituir-se enfim, como humanidade em permanente devir, antes de dar-se os meios de compreensão da sua inconveniência? Intersubjetividade como "experiência vivida"106 e o recurso à significação como recusa do objetivismo na ciência e do mito da autonomia absoluta do espírito - eis duas idéias que permeiam de ponta a ponta, em estado prático, o discurso maquiaveliano. Sobre isso já se disse algo acima: não se parece ser senão para os outros, e o parecer é o âmbito significativo no qual a comunicação verdadeira torna-se possível.

Maquiavel herdou de Aristóteles ${ }^{107}$ a idéia de um tempo cíclico, tanto no sentido de que todas as formas de governo tem começo e fim (tal é o que se infere da arquitetura do Príncipe) como no de que essas formas sucedem-se umas às outras numa ordem teoricamente determinada, mas não fatal ${ }^{108}$. O tempo merleau-pontiano é aberto: os homens constróem o seu futuro nesse movimento em que, "entrando no mundo", eles se "utilizam dele", ao mesmo tempo lhe conferem um sentido novo. A história cíclica é menos aberta que a história como invenção de Merleau-Ponty e Lefort; mas ela expressa, mais que a história aberta, o pessimismo da previsão (nada é estável, como desejaríamos, e a interrupção do ciclo demanda uma virtú, quase divina). A história aberta é por definição e até certo ponto, objetivamente indeterminável - ela não se descreve em ciclos, nem como processo ou decadência inelutáveis - e por isso mesmo ela é de nossa responsabilidade. Ambas as concepções, contudo, não são compatíveis com o otimismo milenarista em qualquer das suas versões: nem com o sagrado (a redemptio pela graça agostiniana, em conexão com o Apocalipse de São João) ${ }^{109}$, nem com o acesso à Lei divina ou Eterna, por via da racionalidade da lei natural ${ }^{110}$, nem com a síntese de Savonarola de comunidade espiritual e soberania republicana ${ }^{111}$, nem com o milenarismo profano, seja ele a crença no Reich de mil anos, a afirmação neo-liberal do fim da história ou a marcha inexorável da história, cientificamente comprovável, em direção à sociedade comunista.

A política do florentino é desencantada; mas a ação política con-

\footnotetext{
106 "La Philosophie et la Sociologie", op. cit., p. 115.

107 The Politics, Livro V.

108 Comentarios, op. cit., I, 2.

109 Augustine, City of God, Pelican Classics, U. K., 1972. No Livro XII, 4, p. 487, Agostinho recusa a concepção da história cíclica; no mesmo Livro, 7, p. 503, afirma a redenção humana pela graça; no Livro XX, 7, pp. 906-10, discute o millenium no Apocalipse e suas interpretações.

110 Aquinas, St. Thomas, Summa Theologiae, vol. 28, Q.93, 3, pp. 59, e Q.94, pp. 75 e ss.

111 Comentado por Pocock, op. cit. p. 104.
} 
tinuada e apaixonada, o esforço quase desesperado de dar forma à contingência e a esperança de realizar de algum modo, e apesar de tudo, a boa ordem, de algum modo, e apesar de tudo, a boa ordem, permitem-nos compreender a exaltação maquiaveliana da virtú sob a luz de um humanismo moderno: o que descobre a dignidade do homem ${ }^{112}$ no convívio com a própria finitude e no aprendizado herético - pois que se opõe ao sempiternum hodie escolástico - do tempo histórico. Tal é o herói da "eternité manquée". Vivemos - teríamos sempre vivido desde Homero - a idade da invenção arriscada; se há heróis, hoje, serão os da invenção republicana e democrática. 


\section{RESUMOS/ABSTRACTS}

\section{O INDIVÍDUO E O CIDADÃO NA HISTÓRIA DAS IDÉIAS. (COM UM ENSAIO SOBRE MAQUIAVEL).}

RÉGIS DE CASTRO ANDRADE

Trata-se de publicação de partes inéditas de work in progress do autor, interrompido pela sua morte em 2002. Apontamentos destinados à reconstrução histórica do liberalismo desembocam num estudo praticamente concluído, em que se propõe uma leitura de Maquiavel num registro "aristotélico".

Palavras-chave: História das idéias; teoria política; Maquiavel; Aristóteles.

\section{THE INDIVIDUAL AND THE CITIZEN IN THE HISTORY OF IDEAS (WITH AN ESSAY ON MACHIAVELLI)}

Sections of a work in progress interrupted by the author's death em 2002 are published for the first time. Notes for a historical reconstruction of liberalism culminate in a practically finished study, in which an "Aristotelian" reading of Machiavelli is proposed.

Keywords: History of ideas; political theory; Machiavelli; Aristoteles. 